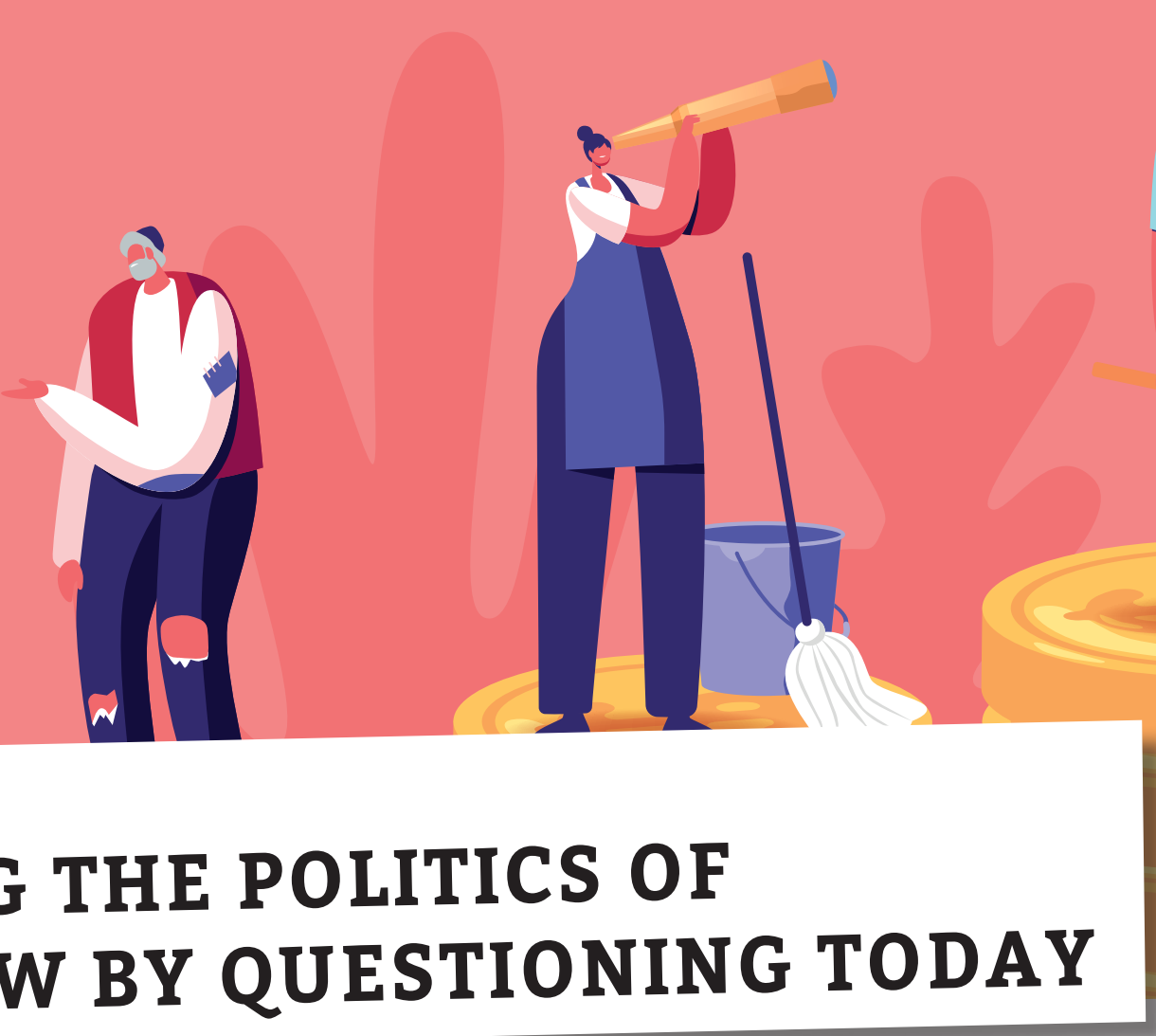

\title{
CHANGING THE POLITICS OF TOMORROW BY QUESTIONING TODAY
}

\author{
DR JONAS PONTUSSON LEADS THE UNEQUAL DEMOCRACIES PROGRAMME BASED AT \\ THE UNIVERSITY OF GENEVA IN SWITZERLAND. THE PROJECT EXPLORES RISING INCOME \\ INEQUALITY AND THE WAYS IT AFFECTS POLITICAL PROCESSES IN LIBERAL DEMOCRACIES
}

It is one of the great shames of the 21 st century that income inequality has continued to rise, with the gap between the rich and the poor becoming an ever-widening chasm. How can it be that there are those with literally billions of pounds, while others do not have enough to eat? The coronavirus pandemic has brought rising inequality into sharp focus, with several recent studies showing that the rich have got even richer as Covid-19 continues to wreak havoc around the world - Jeff Bezos, the founder of Amazon, saw his wealth swell by $\$ 74$ billion in 2020 alone.

Research from Oxfam shows the world's richest 1 per cent have more than twice as much wealth as 6.9 billion people, with almost 50 per cent of humanity living on less than $\$ 5.50$ per day. Despite these shocking and appalling facts, there is a distinct lack of acknowledgement from governments around the world. We might ask if this would be the case if more members of the public voiced their displeasure concerning the situation and there was a clamour for change.

To understand more about citizens' perceptions of income inequality and the role that government might play in combatting it, a team led by $\mathrm{Dr}$ Jonas Pontusson, a political scientist based at the University of Geneva in Switzerland, has embarked on a project that is composed of a survey designed to shed some light on what members of the public think about of income inequality, and what the varying opinions regarding what inequality means are.

WHAT WERE THE THEORETICAL MOTIVATIONS BEHIND THE SURVEY? Jonas has a long-standing interest in the comparative politics of inequality and redistribution. With this survey, he hoped to understand more about how citizens view inequality and why there is not more demand for change. "Income inequality, especially topend income inequality, has risen in most West European countries (as well as the US) over the last two or three decades. Assuming that they are well-informed and self-interested, we would expect low- and middle-income citizens to respond to this development by demanding compensatory policies from government, shifting the tax burden onto the rich and/or increasing income transfers to low- and middle-income households," explains Jonas. "The conventional view is that democracy would lead us to expect governments to respond to the demands of these citizens, since they constitute the majority. But we see very little by way of compensatory redistribution in these countries."

Of course, there could be many reasons for this, such as governments being more responsive to the needs of the rich, but it could also be because low- and middle-income citizens do not behave in a way we might expect. For instance, they might not be aware of what is happening with income inequality, or they might think of inequality in terms of fair rewards for effort and talent. There is the possibility they do not see how government can change the situation, or they have different priorities, such as climate change or immigration. Jonas determined to answer these questions through the survey.

\section{HOW WAS THE SURVEY DEVISED?}

The questionnaire was created by Jonas and three of his collaborators. Many of the questions they asked were taken from previous surveys, which enabled them to compare samples of 


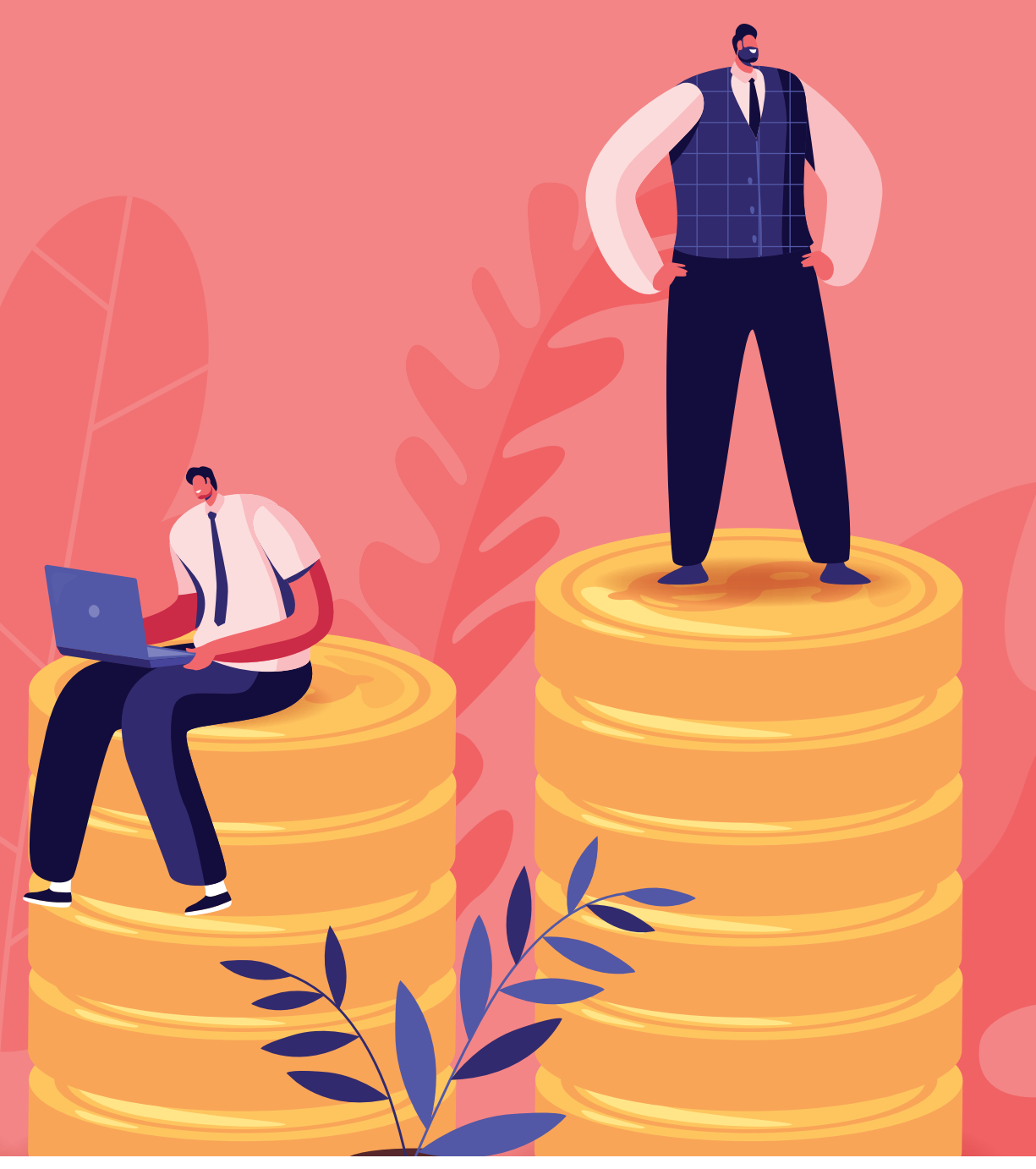

their respondents with those of other surveys. Trying to ensure that the questions were unbiased was an important consideration for the team. "In formulating survey questions, it is important to avoid giving respondents the impression that there is a right answer and to let them know that they have the option not to answer questions they consider to be sensitive," says Jonas. "Equally important, the questions and response options have to be as clear as possible. Before finalising the survey, we had a workshop in which researchers with extensive experience with surveys gave us feedback on our draft questionnaire."

HOW WAS THE SURVEY IMPLEMENTED AND WHAT WAS THE PROCESS FOR ANALYSING THE DATA?

The team used a commercial survey-research company called lpsos, which carried out the survey in 14 countries selected by Jonas and his collaborators. There were at least 2,000 respondents in each country, with a focus on long-standing liberal democracies in Western Europe, as well as the US and other Western European countries with different inequality trajectories over the last 20 years.

Ipsos provided Jonas and his team with the data from the survey around a year ago. Researchers involved in the project are currently analysing the findings and addressing different questions - one is writing a PhD thesis on what shapes people's perceptions of whether inequality is fair and how fairness matters for policy preferences, while others are working on how union members' views of inequality differ from those of other survey respondents.

\section{WHAT HAS THE SURVEY REVEALED SO FAR?}

Generally speaking, the findings show that people are well aware that inequality has risen in their respective countries over the past 20 years or so. Interestingly, it appears as though respondents tend to overestimate the extent of inequality, although they consider other societal problems, such as unemployment and climate change, as being more important than income inequality. "In all 14 countries, large majorities of survey respondents agree with the proposition that politicians are particularly attentive to the policy demands of affluent citizens and corporations. Large majorities also agree that their own views are not very well represented by elected officials," explains Jonas. "Whether or not people are dissatisfied with the way that democracy works, they clearly do not believe that democracy is a 'level playing field'."

Another striking finding is that support for higher taxes on the rich has increased in most countries and so has support for a flat-rate pension and unemployment compensation, as opposed to earnings-differentiated benefits. From this, it appears as if public opinion has moved to the left

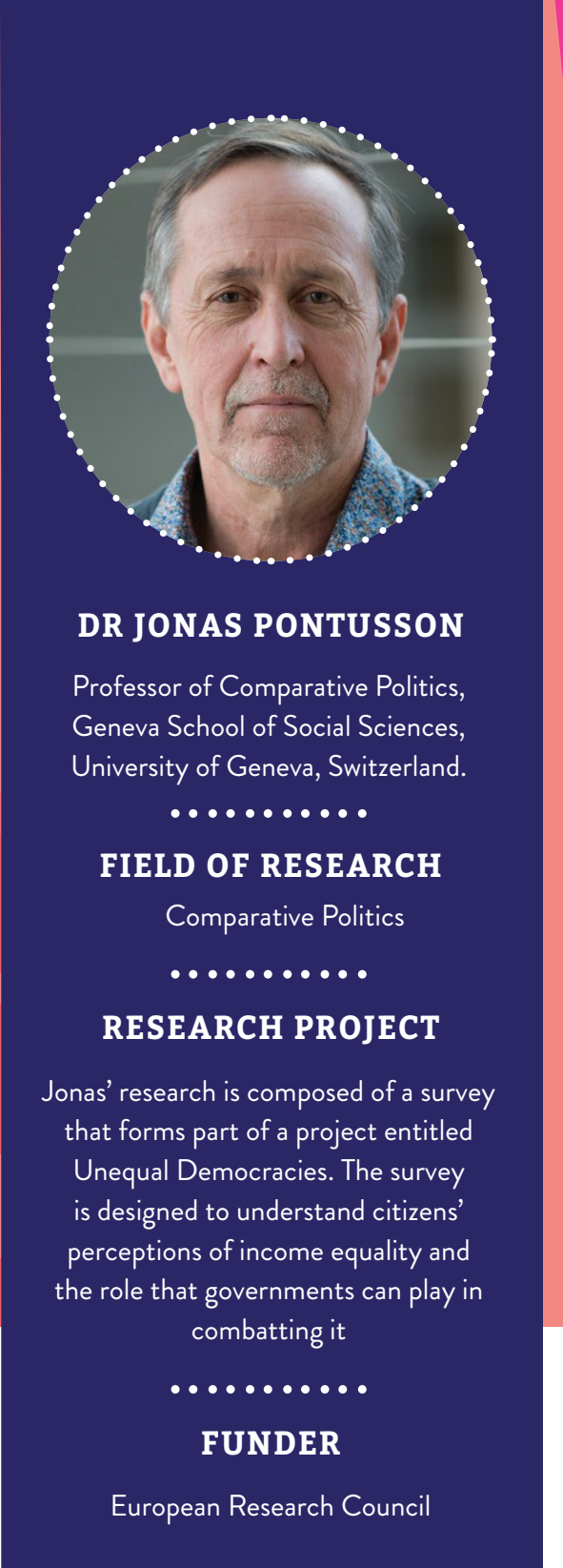

since the economic crisis of 2008-09.

So far, the team's analyses have focused on differences of perception across income groups, but the survey also enables it to explore differences across educational levels and occupational groups. One of the researchers is writing a paper on whether social class is more relevant than relative income for people's attitudes towards inequality. One of the most critical questions is how different forms of income inequality affect political attitudes and behaviour. Currently, it looks as if low-income respondents who perceive politics as biased in favour of the rich are more likely to abstain from voting.

\section{WHAT ARE THE NEXT STEPS FOR THE RESEARCH?}

The team wants to link the survey data on individual attitudes and behaviour to data on country differences in inequality trends and policy outputs. "We want to understand whether the shift to the left has been more pronounced in countries where top income shares have risen most dramatically," says Jonas. "We also want to determine the extent to which policy makers have responded to this shift in public opinion - if at all." 


\section{ABOUT COMPARATIVE POLITICS}

Politics affects every one of us in some way. The pandemic has shown us how government policy can affect the citizens of any given country in myriad ways; the UK has recently suffered its 100,000th death from Covid-19, while countries such as New Zealand have all but eradicated the virus. That is not down to pure chance - it is heavily related to the measures that have been put in place by the governing party (it is worth acknowledging that it is more complex than this and is also clearly related to citizens' behaviour - although this can also be linked to the government within a given country).

Comparative politics is a branch of political science that seeks to use varying methods to explore and understand politics within different countries around the world. In many ways, it is a huge undertaking, if only because there are so many complex reasons for people thinking and acting in the way they do that accessing a definitive answer to related questions is very challenging.

As Jonas' survey has shown, there are parallels and distinctions that can be made across countries, ones that serve to shed light on specific situations. By engaging with comparative politics, Jonas is attempting to understand what people think about inequality and - perhaps more importantly - why they think in the way that they do.

\section{WHAT DOES JONAS FIND}

REWARDING ABOUT HIS FIELD?

Jonas really enjoys the breadth of activities within his work. "I love the combination of research, training researchers and teaching undergraduate students," explains Jonas.

"Research focuses on very specific questions and often becomes quite technical - it is an interesting challenge to explain to students aged 18 or 19 why these questions are important and how they relate to the pressing questions of our times."

\section{HOW DOES JONAS STAY MOTIVATED?}

The project's focus on income inequality and the statistics that are highlighted at the beginning of the article are disheartening. Reading and researching some of the findings highlights some of what is unfair about the world that we live in. However, the fact that Jonas and other researchers are conducting such research is heartening and encouraging - bringing about change can only be achieved by questioning today's realities, and understanding people's opinions is a huge part of that.

It is always worth keeping in mind that there is plenty that is beautiful and brilliant about our world. "My own children, their friends and most of the students that I meet at the university are kind, tolerant people," says Jonas. "They are committed to progressive solutions to the social and environmental challenges that we face today, which certainly bodes well for the future."

\section{WHAT DOES JONAS SEE FOR THE} FUTURE OF DEMOCRACY?

Clearly, there are many problems around the world, but Jonas believes that identifying solutions is not the difficult part - the issue is finding politicians who are committed to implementing solutions. "Over the last 20 or 30 years, mainstream political parties have increasingly competed for the support of relatively affluent middle-class voters and have tended to ignore the uneducated, the poor and immigrants - citizens and non-citizens who often do not vote and who lack other ways to make themselves heard in politics," says Jonas. "Political elites have tended to assume that the 'low-educated' constitute a rapidly diminishing minority of citizens. In the context of rising inequality, economic stagnation and populist backlash, political elites have, belatedly, come to recognise that neglecting the people in the bottom half of the income distribution is not politically viable. I worry about the authoritarian nature of some populist politicians - Trump in particular - but, on the whole, I see the 'populist challenge' as a much-needed wake-up call for mainstream political parties."
HOW TO BECOME A POLITICAL SCIENTIST

- YouthPolitics UK is an award-winning, nonprofit organisation that is dedicated to giving young people a voice:

https://youthpolitics.org.uk/

Teen Power Politics is a large collection of different resources related to various political organisations and causes in the US and beyond:

http://www.teenpowerpolitics.com/tpp_ref.html

The average salary for a political scientist in the UK is around $£ 41,000$, with a minimum of around $£ 27,000$ and maximum of $£ 90,000$, depending on the level of experience.

\section{PATHWAY FROM SCHOOL TO COMPARATIVE POLITICS}

Comparative politics is a sub-field of political science, which is a field you can expect to encounter at university but not at school. However, history, sociology and economics are related subjects and will provide a good foundation for doing research in comparative politics at a later stage in your studies. Statistical skills can also be very useful.

2 or 3 A levels, or equivalent, although you do not necessarily need one in politics to study it at university.

You will need a degree in a relevant subject for postgraduate study.

https://www.theuniguide.co.uk/advice/a-level-choices/what-a-levels-do-youneed-to-study-politics 


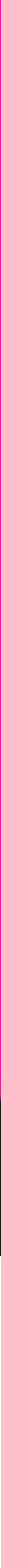

"When I was a kid, I was interested in history and wanted to become a diplomat. However, my encounter with the anti-war movement in the early 1970s set me off in a different direction and I have never looked back.

Having grown up in Sweden, I moved to the US in 1972, at the age of 16. I was shocked by the inequality I saw there. At the same time, I was fortunate to attend a really good liberal arts college in the US, with several truly inspiring teachers. These experiences have informed all my subsequent thinking about politics and society.
I am curious, but also stubborn. I look to challenge what other researchers have said about topics that interest me, digging deeper and pursuing alternative lines of inquiry. I also tend to stick to my guns and keep looking for evidence in support of arguments that $I$ believe in.

Collaboration with other researchers - often younger and better trained than me - has served as a way for me to accomplish things that I could not do by myself. More generally, critical feedback from colleagues and collaborators can be very helpful when you get stuck (and perhaps need to abandon some idea you have come to believe in).

I am proud of having trained a dozen $\mathrm{PhD}$ students who have gone on to do really important research in the domain of comparative politics. I am also proud that I have tackled similar questions using a wide range of different methods over my career."

\section{JONAS' TOP TIPS}

OI The key to being a successful academic researcher, especially a social scientist, is to critically examine conventional wisdoms among people who work on the questions that interest you.

02 Real-world problems should guide the questions that you tackle in your research, so pay attention to what is happening in countries around the world and see what sparks your interest.

03 Inform yourself through mainstream news media, preferably several different media outlets. Mainstream media outlets have biases, but the news they report is not fake. Read the opinion pages and discuss politics with friends and family. 